\title{
Deficit of Health Social Security Fund in National Health Insurance Program: A Case Study of BPJS Kesehatan
}

\author{
Dinil Asyrofi ${ }^{1}$, I Gede Agus Ariutama ${ }^{2}$ \\ ${ }^{1}$ Directorate General of Budget, Ministry of Finance, Indonesia \\ ${ }^{2}$ Polytechnic of State Finance STAN, Ministry of Finance, Indonesia \\ E-mail: igedeagus@pknstan.ac.id
}

Received: September, 2018; Accepted: October, 2019; Published: November, 2019 Permalink/DOI: http://dx.doi.org/10.17977/um002v11i22019p116

\begin{abstract}
BPJS Kesehatan was established to implement national health insurance (JKN). As mandated by PP No. 87/2013, BPJS Kesehatan manages two types of assets carried out separately, namely BPJS Kesehatan and DJSK Assets with the latest poses a more problematic deficit in its financial performance. Thus, the research focuses on the deficit occurred in the DJSK. The method utilized in this study is qualitative case study by interviewing several parties related with the funding of JKN program then processing the data using fivestage data coding. The contribution of this study is the deepening of the factors and solutions to reduce the fiscal burden. The results indicate that the factors causing the deficit include inappropriate structure of contributionbenefit scheme, adverse selection, and insurance effect. Whereas the solutions offered are to raise the contribution premium, adjust the upper limit of the insurance contribution, implement cost sharing, improve the referral system, and implement earmarking for cigarette tax.
\end{abstract}

Keywords: BPJS Kesehatan, National Social Security System (SJSN), Fiscal burden, DJSK deficit

JEL Classification: I13, I18, H40

\section{INTRODUCTION}

National Health Insurance (JKN), universal health coverage (UHC) program in Indonesia, based on Law Number 40 Year 2004 concerning the National Social Security System is one part of the National Social Security System (SJSN) aiming at ensuring that people receive healthcare benefits and protection in meeting basic health needs. Furthermore, it is designed for all people and communities to use the promotive, preventive, curative, rehabilitative and palliative health services needed effectively without being exposed to financial difficulty (WHO, 2014). The importance of a country providing a UHC system is because not everyone can be covered by private insurance program. Harvey \& Gayer (2013) argued that health services were unique since companies/private parties themselves (who provided them) could not be fully expected to overcome the issues of universal health coverage.

Dartanto, et al. (2015) stated that an important milestone in the implementation of JKN in Indonesia was the issuance of Law Number 24 Year 2011 concerning the Healthcare Social Security Agency (BPJS Kesehatan) as a form of Universal Health Coverage (UHC) provision for all communities so as to 
increase health financing and access. WHO (2018) defines UHC as a condition when all residents obtain the necessary health services without causing difficulties in terms of payment to obtain it. UHC is one of the targets in the 3rd Goal of the 17 Goals in the Sustainable Development Goals (SDG's) programmed by the United Nation Development Program (UNDP, 2018). To realize UHC in Indonesia, an implementation guide has been made in the form of the Road Map 2012-2019 by the government (Indonesia, 2012). Two important stages in the Road Map are (1) the establishment of an agency that is responsible for the management and implementation of UHC, namely BPJS Kesehatan which commenced operations on January $1^{\text {st }}$, 2014, (2) coverage of all citizens in JKN membership in 2019 (Simmonds and Hort 2013).

In contrast with PT Askes, previous health insurance provider, BPJS Kesehatan manages two types of assets, namely assets of BPJS Kesehatan and assets of the Health Social Security Fund (DJSK). The management of both assets must be executed separately so that the implication is both assets are treated as different accounting entities and are required to prepare two different financial reports as regulated in Government Regulation Number 87 Year 2013.

Related to its implementation, from the beginning of operation in 2014 to 2016 the DJSK managed by BPJS Kesehatan always received equity capital or grants from central government in order to overcome the cumulative deficits occurring in DJSK. In accordance with Figure 1, it was illustrated that the financial performance of the Health Social Security Fund always suffered a deficit in 2014 and 2015. Whereas, the positive financial performance in 2016 was due to several things, specifically the government assistance, an increase in contribution income due to participants addition, and the lower claim compared to that in 2015. Yet, the cumulative deficit in DJSK is still quite large.

In a preliminary interview to the Head of Sub-directorate of State Budgeting I, it was mentioned that BPJS Kesehatan had no problem in financial issues as BPJS Kesehatan obtained assets from PT Askes as much as eleven trillion rupiahs. However, the problem lied in the DJSK. Therefore, the focus of this research is the Health Social Security Fund (DJSK) deficit.

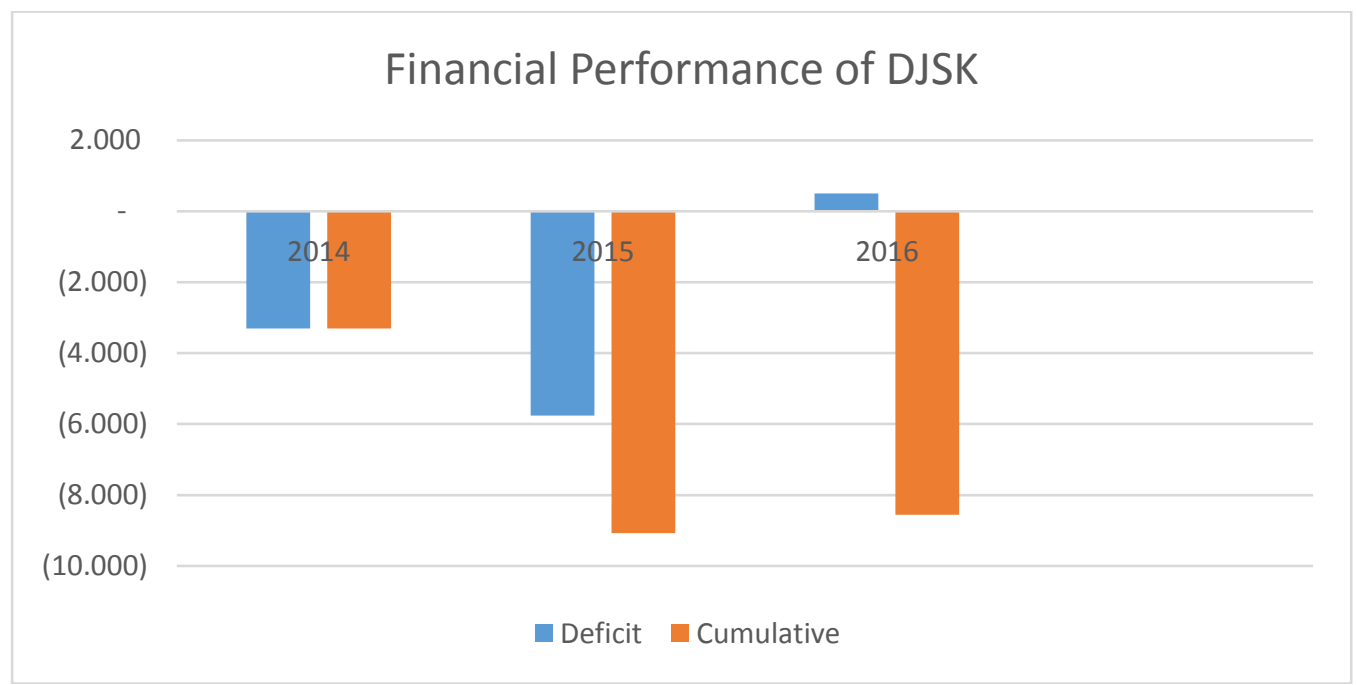

Figure 1. Development of Asset for DJSK.

Source: processed from financial statements of BPJS 2014-2016 (Kesehatan, 2018) 
Financing from the government to overcome the deficit of the DJSK is carried out every year in the form of funding reserves in the State Budget realized to increase liquidity or finance the deficit (Keuangan, 2018). From the Indonesian Financial Note, the government allocates funding each year to control the deficit in DJSK with an increasing percentage compared to the realization of the APBN. This makes the allocation seem to be part of the government mandatory spending outside of government contributions to BPJS participants who receive contribution assistance (PBI participants) which have been mandated by law. This condition makes the burden of state budget quite large resulting in a more limited fiscal space posing a threat to the sustainability of government financial capacity (Heller, 2005).

The deficit experienced by DJSK raises a big question about the real problem. Soft budget constraint theory described by Kornai, Maskin, \& Roland (2003) as loosely defined budget conditions which are usually applied to government institutions or state-owned enterprises might be able to describe the problems that occur in BPJS Kesehatan. They further argued that Universal Health Coverage (UHC) mostly applied soft budget constraint and the problems, which included high bargaining power, inefficiency, and too high costs were tolerated in the hope that the deficit experienced would be covered by government budget. Meanwhile, continuous funding from the government will pose a threat to fiscal space. When fiscal space has been widely used for programs that are mandatory, the space for other programs that are discretionary becomes limited (Heller, 2005). In addition, Law No. 40 Year 2004 concerning the SJSN states that BPJS Health is required to establish technical reserves with the standard of actuarial practice that are common and generally accepted. Meanwhile, Government Regulation No. 87 of 2013 concerning Social Security Asset Management states that the financial health of the Social Security Health Fund assets is measured based on claims for a specified period of time, which means mandated technical reserves. This raises questions about the government's fiscal capacity to close the technical reserve deficit considering the government's limited fiscal capacity. Thus, this study is intended to assess the factors causing the deficit of DJSK along with possible shortterm and long-term solutions to reduce central government fiscal burden to manage national health insurance deficit.

Harvey \& Gayer (2013) define pure public goods as commodities / goods whose consumption is non-rivalry and non-excludable. Furthermore, they classified one form of public goods as publicly provided private goods which are goods that are not actually public goods but are derived from private property, which means that they can only be used with sacrifice, but sometimes provided by the government for free. The substance of public goods provided by the government according to Mankiw (2015) is public goods must be provided by the government when the market is unable to provide them. Harvey \& Gayer (2013) further mention Medicare and housing as examples of goods publicly provided private goods. Therefore, the national health insurance program is one form of the provision of public goods which originally is private goods.

Social insurance is government program to offer insurance by providing protection to the public against adverse conditions which one of them is health insurance (Harvey \& Gayer, 2013; Gruber, 2013). However, Harvey and Gayer (2013) explained that the implementation of social insurance can lead to moral 
hazard for the community, specifically in the form of deviations of one's behavior beyond the will of the government as the insurer. In addition, moral hazard can also cause inefficiencies in the implementation of health insurance programs especially the cost. Moral hazard is usually caused by the motivation of people to obtain personal benefit from social insurance program, public or private, without meeting the requirements to get it. Therefore, the issues related to the implementation of National Health Insurance program in Indonesia require close supervision and applicable solutions to minimize the risk of deficits.

\section{METHOD}

This study aims to look carefully and completely at the root causes of DJSK deficits and the application of alternative solutions between parties related to the implementation of National Health Insurance by BPJS Kesehatan. Therefore, the research method in this study is qualitative case study in which researchers investigate carefully a program, event, activity, process, or group of individuals (Creswell \& Creswell, 2017) and understand a particular problem or situation very deeply and people can identify information-rich cases (Patton, 2006).

The data to be used is derived from primary data obtained from interviews, while secondary data is in the form of literature study by reviewing relevant documents and literature. The informants are from three parties, specifically policy makers (government), organization implementing the program, and experts. The parties involved in this study were selected based on their knowledge and experience related to the problem of the DJSK deficit. The informants are 1) two managers from Directorate General of Budget (DJA) whose duties are preparing policy studies, recommendations, evaluations and preparation of budgeting regulations in the Healthcare Social Security and SJSN; 2) a manager from Ministry of Health whose duty is to prepare policy and evaluation in healthcare financing and insurance; 3) a member of National Social Security Council (DJSN) which is external trustee whose duty is to monitor and evaluate financial condition of BPJS Kesehatan; 4) Assistant Deputy for Treasury and Investment of BPJS Kesehatan; 5) two experts in Health Economics from Fiscal Policy Board (BKF) and Institute for Economic and Social Research (LPEM), University of Indonesia.

Sugiyono (2009) describes the stages of data analysis in qualitative study including data reduction, data presentation, and conclusion. The data obtained from interview and literature study were reduced by choosing, summarizing, selecting the main things, and focusing on the important things to look for themes and patterns. The data collected by the authors are then processed using the method of data coding through five stages (Booth \& Carroll, 2015) specifically familiarization, identifying a thematic framework, indexing, charting and mapping and interpretation. After that, the data is presented in the form of tables and narrative texts and concluded.

\section{RESULTS AND DISCUSSION \\ General Description of National Health Insurance (JKN)}

Presidential Regulation No. 12 of 2013 concerning Health Insurance regulates that the design of the JKN program is compulsory and covers all Indonesian citizens which is in accordance with the concept of universal health coverage (UHC). In realizing this, it is mandated that by 2019 the entire population 
of Indonesia have been included in the JKN program. Participants of JKN program are grouped into two main segments, namely Non-Contributing Members (PBI) and Contributing Members (non PBI). PBI participants are participants whose contributions are borne by the government through state or regional budget, while Non PBI participants are grouped based on the job characteristics of each segment consisting of wage-recipients, non-wage recipients (informal workers and nonworkers), and retirees and veterans.

\section{Contribution, benefit and deficit of Health Social Security Fund (DJSK)}

As the participation in the JKN program increases, the amount of contribution, as a source of income in the DJSK Asset, has also increased since 2014 with an average increase of $28.6 \%$. On the other hand, payment of health insurance benefits has also risen with an almost equal percentage as illustrated in figure 2. Figure 2 indicated that in 2014 and 2015 the number of benefit claims exceeded the total contribution income, resulting in a considerable cumulative deficit.

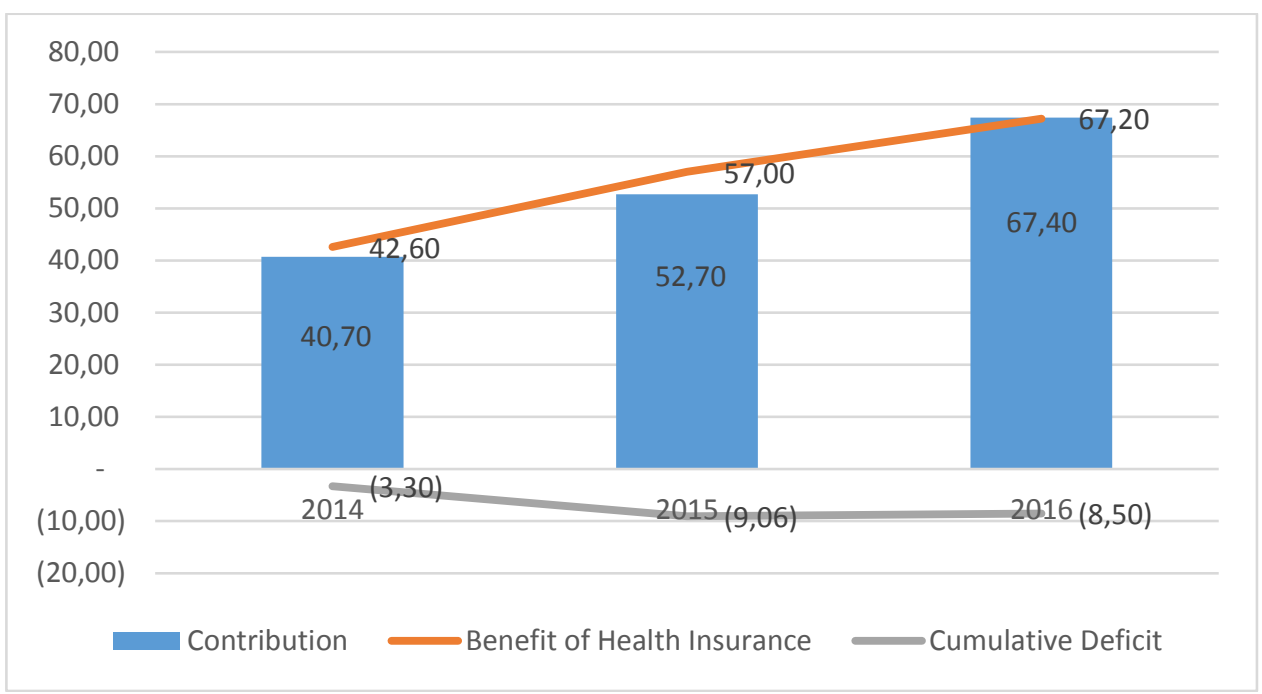

Figure 2. Contribution and Benefits of JKN program

Source: processed from financial report of BPJS Kesehatan 2016 (Kesehatan, 2018)

The discrepancy between contribution fees and benefit payments with the latter is higher in the implementation of JKN program results in deficit occurring every year. The contribution structure currently applied to each group of participants based on the Presidential Regulation on Health Insurance is as follows:

1) PBI (Non-contributing) participants' contribution fee is Rp23.000,- which is disbursed by government and the payment system is regulated in Minister of Finance Regulation Number 10/PMK.02/2018.

2) Wage recipients' contribution from Civil Servant, National Armed Forces, Indonesian Police, High-ranking Government Officers, and Non-Civil Servant Government Officers is as much as $5 \%$ of salary/wages, with details $3 \%$ is paid by employer (government) and $2 \%$ is paid by participants.

3) Wage recipients' contribution from members working in State-owned Enterprises, Regional-owned Enterprises and Private Companies is 5\% of salary/wages, with details $4 \%$ is paid by employer and $1 \%$ is paid by 
participants. The maximum limit of salary or wages as a basis for calculating the contribution amount is Rp8,000,000.

4) Non-Wage/Independent Recipients' contribution is Rp30,000,- for the third class facilities, Rp51,000, - for the second class facilities, and Rp80,000,- for the first class facilities in the hospitals.

For the benefits of health services in the JKN program, the participants, according to the member of DJSN, can access unlimited health services as long as meeting the requirements and in accordance with medical needs. The description of the claims ratio which means gap between contributions paid by participants to BPJS Kesehatan and claims for the cost of health services received is explained in table 1. It can be described that for several segments the JKN participants have a very high claims ratio of $\pm 300 \%$ above the contributions paid.

Table 1. Claims Ratio per Classification of Participants

\begin{tabular}{lccr}
\hline \multicolumn{1}{c}{$\begin{array}{c}\text { Classification of } \\
\text { Participants }\end{array}$} & $\begin{array}{c}\text { Cost of Health } \\
\text { Service }\end{array}$ & Contribution & Claims Ratio \\
\hline $\begin{array}{l}\text { Recipients from } \\
\text { central government }\end{array}$ & 17.402 .841 .793 .434 & 24.814 .983 .852 .125 & $70,13 \%$ \\
subsidy & & & \\
$\begin{array}{l}\text { Recipients from } \\
\text { regional government }\end{array}$ & 4.375 .495 .464 .507 & 3.658 .718 .619 .463 & $119,59 \%$ \\
subsidy & & & \\
Wage recipients & 20.663 .811 .132 .223 & 31.565 .841 .175 .054 & $65,46 \%$ \\
Independent workers & 18.508 .930 .356 .211 & 6.150 .288 .624 .110 & $300,94 \%$ \\
Non workers & 6.296 .807 .176 .232 & 1.607 .579 .906 .784 & $391,69 \%$ \\
\hline $\begin{array}{l}\text { Source: compiled from program management and financial report of BPJS Kesehatan } \\
\text { 2017 (Kesehatan, 2018) }\end{array}$ & & &
\end{tabular}

After exploring the general description, contribution and benefits, as well as deficit of JKN program, it can be concluded that Health Social Security Fund (DJSK) has the possibility to experience more deficit if there is no adjustment in the current system. The problem of the DJSK deficit is not only limited to accounting calculations, but also requires a deeper assessment. Thus, intensive and deep analysis on the causal factors of DJSK deficit along with the applicable shortterm and long-term solutions are required to guarantee the financial sustainability of BPJS Kesehatan.

\section{Analysis of Factors Causing the Deficit of DJSK}

Before discussing the factors leading to the DJSK deficit, it is important to identify its impact on the national health insurance (JKN) system. Informant from Ministry of Health mentioned that the impact of the deficit was considered to be quite systemic to health services due to the claims for reimbursements by the hospitals to BPJS Kesehatan usually took months so that hospital cash flow did not run properly. It is in line with the statement from member of DJSN who found that the period of payment for claims submitted by hospitals exceeded the time limit, thus impacting on health services provided, reducing benefits and longer waiting times for services.

After discussing the effect of deficit on JKN system, the causal factors related to the deficit of DJSK hereafter will be discussed. 


\section{Unmatched contribution and benefit structures}

Related to the cause of DJSK deficit, the informant from DJSN mentioned that the deficit was caused by inappropriate structure of contribution and benefit particularly low contribution from insurance members with unlimited benefits based on the medical needs. The medical needs of the recipients are not limited by the amount of benefit per person per period, and everyone can use these benefits in full if they meet medical needs and condition. For the calculation of current contribution, the assumption is still using the old one which is already irrelevant so that the amount of the contribution needs to be reviewed.

In line with the discussion above, interviewees from Directorate General of Budget and expert from University of Indonesia also mentioned that deficit of DJSK will certainly occur as the contribution paid is always smaller than the benefits received. Furthermore, expert from BKF added that the average ratio between contributions and benefits of each participant is one in two, for example someone pays a premium fee of Rp1,000, - while the benefits he earns are Rp.2,000. Based on the discussion, it can be concluded that there is discrepancy problem between contribution and benefit structures of national health insurance program. This condition is in accordance with the study of Situmorang (2016) which found that there was a funding gap between contributions and benefits with an increase of $58 \%$ per year. This means that the contribution that is currently applied in the JKN program is smaller compared to the benefits of the services provided so that it impacts the gap.

Additionally, the problem above is intensified by another problem contributing to the deficit, particularly the amount of premium that are under the calculation that should be. This issue was expressed by the informant from BPJS Kesehatan who said that based on the calculations made by the BPJS, the contributions currently applied are below what should be, especially for PBI premiums. This is in accordance with the opinion of the participant from DJA and UI mentioning that the premiums currently paid by participants, especially contributions from PBI were indeed by design was lower than the actuarial calculation and lower than the contributions paid by independent participants class III. The determination of the amount of participant contribution is regulated through a Presidential Regulation on Health Insurance as amended the latest by Presidential Regulation Number 19 of 2016 as the second amendment to Presidential Regulation Number 12 of 2013 concerning Health Insurance. In this regard, the interviewee from Harmonization Section of the Social Security Health Regulations argued that the stipulation with the Presidential Regulation also became an obstacle when fee adjustment was required. According to him, the regulation should be stipulated by regulation that was easier to change.

\section{Insurance Effect}

Another causal factor of DJSK deficit is the existence of insurance effect, specifically the condition when people compete to use their health insurance as a result of the implementation of a new health insurance program. Interviewee from UI explained about the existence of insurance effects when national health insurance was initially implemented. This phenomenon, according to him, is like over utilization, for example people are more likely to use health facilities even 
though they may still be able to heal themselves without having to go to the health facility. A similar opinion was expressed in an interview with the interviewees from DJA and Ministry of Health who revealed that the insurance effect in the early years of implementation like visiting doctors more often was indeed a common thing in every country that implements a national health insurance program.

In line with the opinion of the interviewees, Head of Sub Directorate of State Budget Expenditures I mentioned that at the beginning it was implemented, especially in 2015 and 2016 the JKN program participants were too excited over the new program so as to compete to use it. He added that this condition was supported by the existence of imperfect referral system resulting in participants being able to directly seek treatment at advanced health facilities without going through first-level health facilities.

However, a differing opinion was expressed by interviewee from BKF who although basically agreed with the existence of insurance effects, the behavior actually had a positive side, particularly directing participants to get preventive services to reduce the possibility of getting more severe treatment in the future which can prevent a larger claim later on. Goetzel (2009) defined the word "preventive" service in health insurance as a broad term that includes interventions aiming to reduce the occurrence of diseases and disabilities or to slow the progression of the disease. Preventive services in a more concise sense are efforts to prevent disease.

The findings about the insurance effects above are in line with the study of Wen, Tsai, \& Chung (2008) which found that with the application of social insurance in Taiwan, people visited health services more often, especially for outpatient treatment, twice as much as before. In the study it was concluded that the existence of health insurance can eliminate or reduce community barriers to access health services.

\section{Adverse Selection}

Based on the information from several sources, there was another factor contributing to the health social security fund deficit, namely adverse selection. Interviewee from Ministry of Health explained that social insurance is inseparable from the presence of adverse selection, especially for catastrophic diseases because the type of disease requires huge amount of money and long-term treatment. In line with this, the Head of Sub Directorate of State Budget Expenditure I mentioned the same thing that those who registered were people who were sick or who were at high risk, and they usually were independent participants.

This opinion is similar to the opinion of the interviewee from UI who revealed that adverse selection did occur, especially for voluntary participants such as independent participants. He said it because of the nature of independent participants which was voluntary registration, meaning that people who were at high risk had a tendency to register. If someone is healthy, he or she is most likely not willing to register because the risk of being sick is low. In other words, there is no reason to register as a member because he will not use the insurance.

Based on the discussion, the adverse selection phenomenon also contributes to the cause of the DJSK deficit. Harvey \& Gayer (2013) described the adverse selection phenomenon by stating that participants with low risk, in this case a healthy community, are reluctant to become insurance participants, but the opposite 
condition occurs in high-risk communities who will be interested to become insurance participants since one of the considerations is that the medical expenses will be borne by the health insurance program.

\section{Short-Term Solutions to Reduce DJSK Deficit}

Questions about solutions to overcome DJSK deficits have been asked to all interviewees. However, according to the researcher at BKF, the deficit condition in national health insurance did indeed occur in other countries. He mentioned that based on the experience of several countries he knew, health insurance especially Universal Health Coverage inevitably experienced deficit, so there would definitely be an injection of funds from the government. The next question should be how to reduce the deficit to reduce the burden of state budget.

The same thing was also conveyed by the Subdivision Head of Financing and Participation Analysis by quoting the WHO headquarter statement that government subsidies for the implementation of national health insurance would certainly exist in any country. This means that the presence of these bonds shows a deficit. Therefore, what can be done is solutions or efforts to reduce the deficit. The short-term solutions which are to overcome funding difficulties when the deficit of current DJSK occurs to ensure that the national health insurance program continues to run are as follows:

\section{Withdrawing the PBI (non-contributing members) contribution in advance}

The first solution is to withdraw the PBI contribution several months earlier. It was expressed by several interviewees from DJA, BPJS Kesehatan, Ministry of Health and National Social Security Board. They revealed that in order to overcome cash flow difficulties occurred because of the health social security fund deficit, withdrawing PBI contributions 3 months in advance should be executed. The PBI contribution drawn in advance is not only used to cover the deficit in the current year, but is also used to cover the deficit from the previous year.

\section{Expanding the Participants Coverage}

The next solution proposed is to expand the coverage of participants. It was declared by interviewee from UI who expressed the opinion that as the government was not yet willing to raise the contributions, it was better to increase the membership as well as to achieve the UHC target in 2019. His reason to expand the coverage was that adding participants meant that it would increase the amount of contributions along with the addition of healthy participants. In contrast, the Deputy Director of Treasury and Investment disagreed with the solution. According to him, the addition of participants would increase the contributions insignificantly when compared to the additional costs from the benefits claimed. He further argued that since the gap between unit cost of the contribution and the actuarial count was too far, thus, based on our projections, adding the participants would not increase contributions significantly as the increase in health care costs was higher than the increase in the contributions.

Deducting General Allocation Fund (DAU) and Revenue Sharing Fund (DBH) for local governments that have not paid contributions 
As stated by interviewee from the Head of Harmonization of the Health and Social Security Regulation, the government has now issued a Regulation of the Minister of Finance (PMK) concerning cuts in General Allocation Funds and Revenue Sharing Funds for local governments that are negligent to pay contributions to BPJS Kesehatan. The PMK referred to is PMK Number 183/PMK.07/2017 concerning Procedures for Settlement of Arrears in Local Government Health Insurance Fees through Cutting of General Allocation Funds and / or Revenue Sharing Funds. Explanation related to this matter was further conveyed by the informant from BPJS Kesehatan saying that the local government arrears that had been mutually agreed between the regional governments and BPJS branch offices amounted to Rp470 billion and both parties have signed the report of reconciliation. The arrears are derived from the local governments to pay local governments' civil servant contributions of 3\% per month that have been overdue since 2004. For the contribution of local governments to local PBI participants, there was no problem because the contributions were purely from the local government so that if the local government is in arrears, the relevant PBI participant cards will be deactivated. However, for the local government civil servants' contributions in arrears, BPJS Kesehatan could not deactivate their membership cards since the civil servants have already paid their share of premium. This solution was categorized as a short-term solution because the deduction of DAU and DBH has been agreed that the deduction would be carried out in stages so that it could be used to cover the deficit for 2 years.

\section{Possible Long-term Solutions to Reduce DJSK Deficit}

Some solutions that can be applied to reduce deficits in the long run include the following:

\section{Increasing the premiums based on the actuarial calculation}

In an interview, the participant from BPJS Kesehatan explained that overcoming the DJSK deficit could be carried out by raising the contribution premium according to the actuarial calculation. He argued that since the concept of cost-sharing was rejected by the government, the possible solution is to make the premiums sufficient, in other words was to raise premiums. In line with this, interviewees from DJA stated that the steps to review the amount of premiums were things that could be used as an instrument for medium and long-term solutions to overcome the DJSK deficit. However, related to efforts to readjust this contribution amount, interviewees from BKF and DJA said that the determination of the amount of the contribution was not merely a matter of actuarial mathematical calculations, in reality, but there were also political interventions. Furthermore, they also revealed that at present the government chose not to raise the contributions in advance, because welfare policies were closely related to politics.

\section{Adjusting of the Upper Limit of Contributions}

The solution that can be applied next is to readjust the upper limit of the premium, especially for the wage recipients in this case are civil servant, private and BUMN/BUMD employees. According to interviewee from BPJS Kesehatan, for the wage recipients from civil servants, the basis of the imposition of the premium proportion of $5 \%$ was based on basic salary. He suggested that the basis for imposing the percentage should not only be based on basic salary, but could be 
added with other components or based on take home pay to increase the nominal contribution. Whereas for private wage recipients or BUMN/BUMD employees, he revealed that currently there was a maximum limit on the imposition of premium as much as salary of eight million rupiah. Therefore, he proposed that this upper limit be raised or even eliminated so that it could increase the nominal contribution.

Interviewee from DJA also conveyed the same thing, that in order to increase contribution, adjustments should be made to the upper limit as a basis for calculating the percentage of contributions. The logic is that the amount of contributions for wage recipients was based on a certain percentage, so by increasing the upper limit of the contribution, the nominal contribution that must be paid by the group of participants would also increase.

\section{Implementing cost sharing/copayment}

Another solution to overcome the health insurance social deficit is cost sharing or copayment as conveyed by interviewee from UI. He believed that this copayment would increase contribution income and it could also reduce benefit claims because people would be more careful in making claims. Furthermore, the cost sharing could be in the form of percentage of the cost of health services or certain nominal.

Interviewee from DJA also supported the implementation of cost sharing to reduce DJSK deficit, however, the implementation, according to interviewee from BPJS Kesehatan, has not been approved and permitted by the government currently. The application of cost sharing is in accordance with the study by Harvey \& Gayer (2013) that cost sharing was needed to reduce moral hazard that occurred in the health insurance system.

\section{Improving referral and back-referral systems}

Informant from DJA explained the effort to clarify the enforcement of the referral and back-referral system between the primary, the secondary and tertiary health facilities. One of the aims is to avoid double charges because the primary health facilities have received capitation payments every month. He gave an illustration for treatment that should have been done at the primary level of health facilities for 155 types of diseases determined, however, due to the imperfect referral system the patient was immediately referred to the hospital. This will create double payments, as the health service that should be financed at the primary level health facility with capitation, are reimbursed again with Indonesia Case Base Groups (INA-CBG) because of being referred to the hospital.

A similar opinion was expressed by the informant from BPJS Kesehatan who mentioned that the effort to clarify the referral and back-referral system was in order to control utilization. As an illustration, for people who routinely go to the hospital, BPJS Kesehatan made a referral program so that they did not need to go back to the hospital like a diabetic person who had to take medication every day. He was given enough medication and he was stable, thus, he did not need to go back and forth to the hospital. That was one way to control it so that the hospital cost could be suppressed.

Referral and back-referral system illustrations in figure 3 displayed the tiered referral system as previously described. Patients from the primary health 
facilities can be referred to the secondary/tertiary health facilities and back-referred to the primary health facilities from secondary/tertiary health facilities.

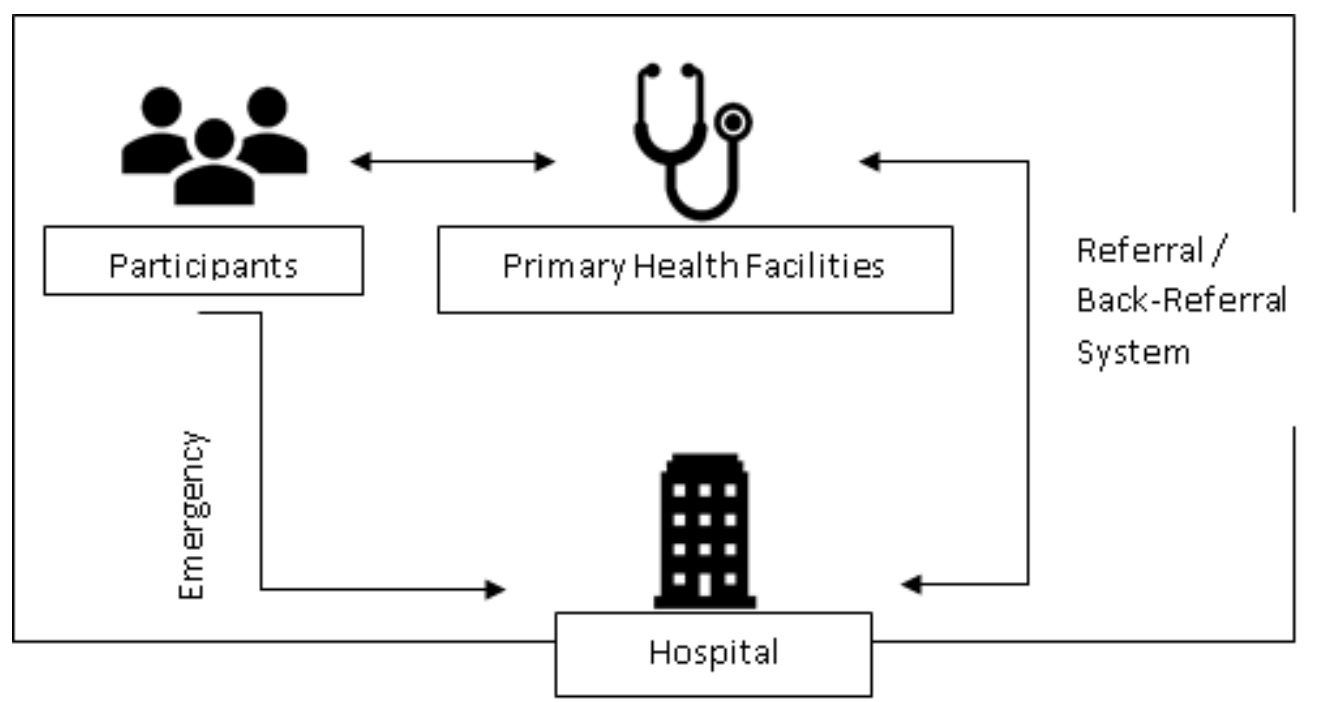

Figure 3. Illustration of Referral and Back-Referral System

Source: Practical Guidebook for Tiered Referral System (Kesehatan, 2014).

\section{Earmarking of cigarette tax}

In an in-depth interview with the resource person from BPJS Kesehatan, he mentioned another solution, specifically the imposition of cigarette tax. He expected that starting in 2019 the cigarette tax would be applied as an additional contribution to DJSK. He argued that the cigarette tax is a sin tax meaning the act of smoking is a contributor to the occurrence of illness for himself and others, which will have a bigger impact on claims of health services for the JKN program.

Based on Law No. 28 of 2009 concerning Regional Taxes and Regional Levies, cigarette tax is one type of provincial tax. Based on the law, it is mentioned that cigarette tax is levied on cigarette excise tax collected by the government. Among the income of cigarettes collected, there is an allocation of at least $50 \%$ for funding public health services and law enforcement by the authorities. Hoffer, Shughart, \& Thomas (2013) explained that the provision of subsidies for the consumption of goods wanted by the majority is a natural thing, but for consumption of goods unwanted by the public would generally be subject to penalties, such as liquor. However, in this study, the imposition of taxes was not only on alcoholic beverages but also on tobacco, in this case cigarette tax.

\section{Improving preventive services}

In an interview with BKF researcher, he proposed to optimize preventive services, rather than focus on curative action. To further, he argued that improving preventive health services can reduce the cost of curative health services in the coming period although it may require more expenditure for the current period. This solution is in accordance with the study of Maciosek, et al. (2010) on the use of preventive services in Health Care programs in America resulting in by increasing the use of preventive services to 90 percent in 2006 it can save costs up to $\$ 3.7$ billion. Thus, based on the study it is suggested that the government can further increase the use of preventive services. 


\section{CONCLUSION}

UHC in Indonesia to provide health protection without experiencing financial difficulties has been implemented since 2014. However, it faced sustainability issue in terms of insurance funding, specifically deficit in DJSK. Based on the results and discussion in this study, it can be concluded that there are several causal factors of the Health Social Security Fund (DJSK) deficit and solutions that can be applied in the long term and in the period of the deficit to ensure the JKN program to continue. The main factor causing the DJSK deficit is the unpaired contribution and benefit structures. Contributions received that were still considered low were used to finance the benefits of unlimited health services. Another problem is the existence of insurance effect in the form of public euphoria at the time of the initial implementation of JKN, encouraging them to use health services more often even though they were only slightly ill. The last cause is adverse selection factor which was a phenomenon where members of the BPJS Kesehatan were people who were already sick or having a high risk, contributing to the greater deficit.

To reduce the deficit caused by the factors discussed, several solutions were offered. For the short term, the first solution that could be proposed includes withdrawing PBI contribution in advance. The second short-term solution was increasing the membership coverage. Furthermore, deducting DAU and DBH from undisciplined local governments was necessary to be implemented to local governments who had arrears of contributions to BPJS Kesehatan.

In addition, several long-term solutions to reduce the deficit of the Health Social Security Fund are also being offered, including: 1) increasing premium based on actuarial calculation; 2). adjusting the upper limit of contribution specifically for wage-recipients; 3) implementing cost sharing system; 4). Improving referral and back-referral systems; 5). earmarking of cigarette tax; and 6) improving and promoting preventive service.

However, among other things, this study does not include quantitative calculations to assess the appropriate amount of premium to be applied in the national health insurance program for each type of participants. So, the next study is expected to consider using quantitative calculation analysis to complete the analysis of this study. In fact, this study provides insights for BPJS Kesehatan and government regarding the impacts of DJSK deficit and causal factors from a number of parties responsible for designing and executing policies related to the funding of BPJS Kesehatan. Furthermore, alternative solutions from the policy makers and executors allegedly make them a lot more applicable. Following the results of the study, it is suggested for BPJS Kesehatan and government by involving academics and experts can calculate the exact amount of premiums for the implementation of the JKN program periodically, accompanied by a more rational follow-up to reduce fiscal burden. This means that if based on mathematical and actuarial calculations the amount of the premium needs to be adjusted so that the amount should be adjusted accordingly.

\section{REFERENCES}

Booth, A., \& Carroll, C. (2015). How to build up the actionable knowledge base: the role of 'best fit'framework synthesis for studies of improvement in healthcare. BMJ Qual Saf, 24(11), 700-708. 
Creswell, J. W., \& Creswell, J. D. (2017). Research design: Qualitative, quantitative, and mixed methods approaches. Sage publications.

Dartanto, T., Rezki, J. F., Siregar, C. H., Bintara, H., \& Pramono, W. (2015). Expanding universal health coverage in the presence of informality in Indonesia: challenges and policy implications (No. 201511). LPEM, Faculty of Economics and Business, University of Indonesia.

Goetzel, R. Z. (2009). Do Prevention or Treatment Services Save Money? The Wrong Debate. Health Affairs, 28, no.1:37-41

Gruber, J. (2013). Public Finance and Public Policy (4th ed.). New York: Worth Publisher.

Harvey, R. \& Gayer, T. (2013). Public finance. McGraw Hill Higher Education.

Heller, M.P.S. (2005). Understanding fiscal space. Washington, DC: International Monetary Fund.

Hoffer, A. J., Shughart II, W. F., \& Thomas, M. D. (2013). Sin taxes: Size, growth, and creation of the sindustry. Mercatus Center, George Mason University.

Indonesia, R. (2012). Peta jalan menuju jaminan kesehatan nasional 2012-2019. Jakarta: Republik Indonesia.

Kesehatan, B.P.J.S. (2018, May 3). Laporan Keuangan Tahun 2014. Retrieved from http://bpjs-kesehatan.go.id/bpjs/index.php/arsip/index/

Kesehatan, B.P.J.S. (2018, May 3). Laporan Keuangan Tahun 2015. Retrieved from http://bpjs-kesehatan.go.id/bpjs/index.php/arsip/index/

Kesehatan, B.P.J.S. (2018, May 3). Laporan Keuangan Tahun 2016. Retrieved from http://bpjs-kesehatan.go.id/bpjs/index.php/arsip/index/

Kesehatan, B.P.J.S. (2018, August 5). Laporan Pengelolaan Program Tahun 2017 dan Laporan Keuangan Tahun 2017. Retrieved from http://bpjskesehatan.go.id/bpjs/index.php/arsip/index/

Kesehatan, B.P.J.S. (2014). Panduan Praktis Sistem Rujukan Berjenjang.

Keuangan, K. (2018). UU APBN dan Nota Keuangan tahun 2014-2018. (Online) Available from https://www.kemenkeu.go.id/informasi-publik/uu-apbn-dannota-keuangan/ (Accessed August 5, 2018).

Kornai, J., Maskin, E., \& Roland, G. (2003). Understanding the soft budget constraint. Journal of economic literature, 41(4), 1095-1136.

Maciosek, M. V., Coffield, A. B., Flottemesch, T. J., Edwards, N. M., \& Solberg, L. I. (2010). Greater use of preventive services in US health care could save lives at little or no cost. Health Affairs, 29(9), 1656-1660.

Mankiw, N.G. (2015). Principles of Microeconomics. Cengage Learning. Stamford, CT, 213.

Patton, M.Q. (2006). Metode Evaluasi Kualitatif. Yogyakarta: Pustaka Pelajar.

Peraturan Menteri Keuangan Nomor 183/PMK.07/2017 Tata Cara Penyelesaian Tunggakan Iuran Jaminan Kesehatan Pemerintah Daerah Melalui Pemotongan Dana Alokasi Umum dan/atau Dana Bagi Hasil. 2017. Retrieved May 5, 2018, from http://www.jdih.kemenkeu.go.id

Peraturan Menteri Keuangan Nomor 10/PMK.02/2018 tentang Tata Cara Penyediaan, Pencairan, Dan Pertanggungjawaban Dana Iuran Jaminan Kesehatan Penerima Bantuan Iuran. 2018. Retrieved May 5, 2018, from http://www.jdih.kemenkeu.go.id 
Peraturan Pemerintah Nomor 87 Tahun 2013 tentang Pengelolaan Aset Jaminan Sosial Kesehatan. 2004. Retrieved May 5, 2018, from http://www.jdih.kemenkeu.go.id

Peraturan Presiden Nomor 19 Tahun 2016 tentang Perubahan Kedua atas Peraturan Presiden Nomor 12 Tahun 2013 tentang Jaminan Kesehatan. 2016. Retrieved May 5, 2018, from http://www.jdih.kemenkeu.go.id

Simmonds, A. \& Hort, K. (2013). Institutional Analysis of Indonesia's Proposed Road Map to Universal Health Coverage. Health Policy and Health Finance Knowledge Hub Working Paper 33.

Situmorang, C.H. (2016). Kesinambungan Pendanaan JKN-BPJS Kesehatan. Jurnal Farmasi Indonesia, Vol. 8 No. 1.

Sugiyono. (2009). Metode Penelitian Kuantitatif, Kualitatif dan R\&D. Bandung: Alfabeta.

Undang-Undang Nomor 40 Tahun 2004 tentang Sistem Jaminan Sosial Nasional. 2004. Retrieved May 5, 2018, from http://www.jdih.kemenkeu.go.id

Undang-Undang Nomor 28 Tahun 2009 tentang Pajak Daerah dan Retribusi Daerah. 2009. Retrieved May 5, 2018, from http://www.jdih.kemenkeu.go.id

Undang-Undang Nomor 24 Tahun 2011 tentang Badan Penyelenggara Jaminan Sosial. 2011. Retrieved May 5, 2018, from http://www.jdih.kemenkeu.go.id

UNDP. (2018, March 11) Sustainable Development Goals. Retrieved from http://www.id.undp.org/content/indonesia/en/home/sustainable-developmentgoals.html..

Wen, C. P., Tsai, S. P., \& Chung, W. S. I. (2008). A 10-year experience with universal health insurance in Taiwan: measuring changes in health and health disparity. Annals of internal medicine, 148(4), 258-267.

WHO. (2014). Making fair choices on the path to universal health coverage. Final report of the WHO Consultative Group on Equity and Universal Health Coverage. Geneva: World Health Organization.

WHO. (2018, July 1) Resolusi World Health Assembly ke 58. WHA 58. 2005. Retrieved from http://apps.who.int/gb/archive/e/e_wha58.html. 